\title{
Multiple Abnormalities in the Skull of a Prostitute. An Autopsy Report (1900)
}

\author{
Marta Licata ${ }^{1}$, Omar Larentis ${ }^{1}$, Chiara Tesi $^{2}$, Silvia Iorio $^{3}$ \\ ${ }^{1}$ Centre of Research in Osteoarchaeology \\ and Paleopathology, Department of \\ Biotechnology and Life Sciences, University \\ of Insubria, Varese, Italy, ${ }^{2}$ Division of \\ Paleopathology, Department of Translational \\ Research and New Technologies in Medicine \\ and Surgery, University of Pisa, Italy, \\ ${ }^{3}$ Department of Molecular Medicine, Unit of \\ History of Medicine, Sapienza University of \\ Rome, Italy \\ Correspondence: \\ marta.licata@uninsubria.it \\ Tel.: + 390332217534 \\ Fax.: + 390332217532 \\ Objective. The study presents and comments on the publication of an \\ autopsy report. Case Report. In 1900 De Blasio published an article \\ entitled "Multiple abnormalities in a prostitute's skull" in the "Journal \\ of Psychiatry, Criminal Anthropology and related sciences". In this \\ work De Blasio related anomalies at the cranial level to the presence \\ of mental pathologies. The skull belonged to a 24 -year-old prostitute \\ who died of syphilitic hepatitis. In his article, De Blasio described the \\ life of the woman, after which he gave a macroscopic description of the \\ skull. De Blasio believed that the subject's amoral behavior was caused \\ by the anomalous shape of the subject's skull. Conclusion. From the \\ study, it is evident that the school of criminal anthropology influenced \\ De Blasio's autopsy medical practice, and it is interesting to note the \\ interpretation of anthropologists of the time who tried to describe the \\ link between physical and behavioral anomalies.
}

Received: 7 April 2018

Accepted: 18 September 2018

Key words: Criminal Anthropology - Abele De Blasio - Morphological Anomaly • Autoptic Examination.

\section{Introduction}

In 1900, Abele De Blasio (1858-1945) (1) a physician and anthropologist affiliated to the Lombrosian School of Criminal Anthropology, published an article entitled "Multiple Anomalies in the skull of a prostitute" in the "Journal of Forensic Psychiatry, Criminal Anthropology and Related Sciences" (2). This is another example of the positivist pseudo-science inspired by social Darwinism, which linked abnormal behavioural traits to irregular anatomy.

We discuss a particular autopsy report by the positivistic school of Italian criminal anthropology.

\section{Case Report}

In this paper, De Blasio describes the skull of Carmela, a 24-year-old prostitute who died of syphilitic hepatitis. During the autoptic examination, De Blasio recorded an abnormality in the shape of the skull (Figure 1) which he believed was the cause of a nervous system pathology (3) and correlated it to amoral behaviour.

The girl was at the age of eleven when she left home and during her life was found guilty of theft and became smeared with human blood as a consequence of scratching her companion. She was then accused of being involved in a criminal offense and for 


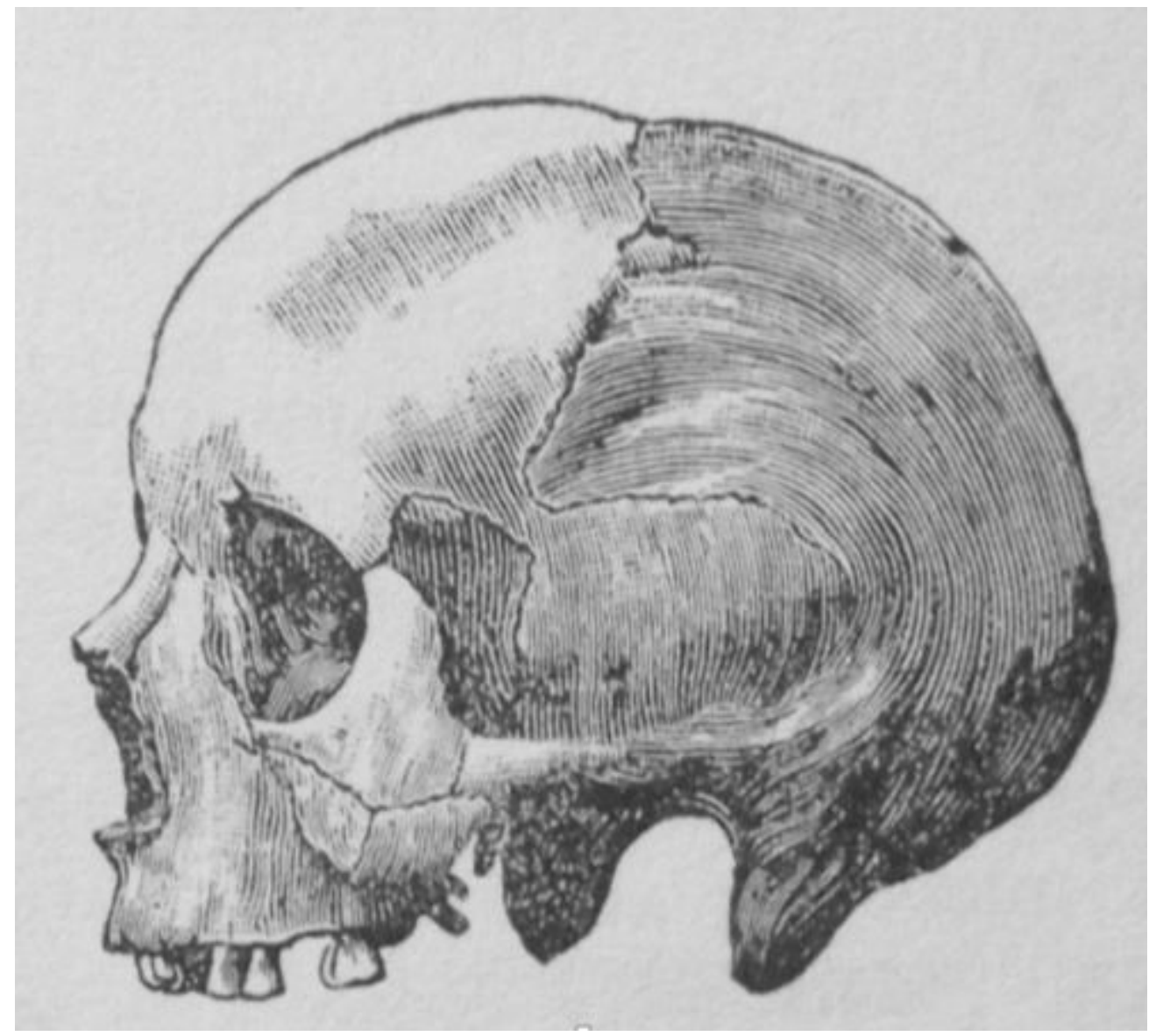

Figure 1. The drawing of the prostitute's skull shows the skeletal anomalies described by De Blasio in the article (2).

breaching regulations, and was placed under special police surveillance. The skull of the woman was described as follows: a narrow and high forehead, large orbital cavities, with thin upper edges, a high and narrow nose opening. The jawbones are divided in two and the upper edge of the upper jawbone resembles the shape of a horseshoe. An anomaly is noticeable in the skull when observed in a lateral plane. It is asymmetric with the obvious manifestation of laterooccipital plagiocephaly. In addition, the sagittal suture is wavy, while the other sutures are jagged. Another important observation made was evidence of a star shaped wormian along the right coronal suture, an extra isolated bone that can occur within a suture in the skull.
Moreover, the presence of accessory bones, in relation to the right and left regions of the parieto-occipital, increases the degree of deformity of the skull. In addition to these malformations, the limited cranial capacity of the subject (1225 c.c.) highlights Blasio's opinion that the brain, contained in such a small and malformed skull, did not allow the person to think correctly $(4,5)$.

\section{Discussion}

In light of this finding, De Blasio cites the opinion of Lombroso who, in his studies of criminal anthropology, considered that one of the characteristics of the delinquent was a skull capacity lower compared to normal 
$(6,7)$. Especially for the criminal woman, Lombroso theorized prostitution as a congenital and anthropometrically measurable defect. In his work "The delinquent woman, the prostitute and the normal woman" ( $\mathrm{La}$ donna delinquente, la prostituta e la donna normale), Lombroso reported prostitution as a regression of the normal woman, equating prostitutes and 'primitive' (non-white) women because the primitive woman was a prostitute $(8,9)$.

A particular morphological anomaly is represented by the division of the jaw bones, which is a rarity in Europe. Some scholars interpret this alteration as an atavistic feature because it has been found in some quadrumans and in invertebrates, including reptiles and fish (10-12).

Another peculiarity discovered by De Blasio during the anthropological study was the lack of a glenoid fossa of the temporal bone. To give a better interpretation of this absence, he cited his colleague, GiuffridaRuggieri, who argued that the absence of this cavity is a feature of non-human primates, especially anthropomorphic apes (13). Finally, De Blasio reports that he even saw the same morphological feature in two specimens of Gorilla savagei.

Interestingly, De Blasio returns to Giuffrida-Ruggieri's interpretation and features it in his contributions. In fact, Giuffrida proposed a comparison between the presence and absence of the glenoid cavity of the temporal bone between the skulls of alienates and those of delinquents. Responding to the lack of the glenoid cavity in the temporal bone in some skulls belonging to these two categories ( 13 out of 1000 in the first and 1 in 25 in the second), it is clear that the authors' intention was to interpret this feature as an element that could be evident in people who possess limited intellectual capacities. As for the presence of accessory bones, De Blasio, using the studies of Marimò and Bianchi, demonstrated that the existence of this characteristic increased to $1.67 \%$ in criminal subjects. One of the other skeletal anomalies found in the young woman was plagiocephaly, a deformation of the skull bones that occurs in infants, which gives the head a parallelogram shape. According to De Blasio, the possible causes of this malformation were: rickets, uterine contractions, adaptation of the head of the foetus in the spoiled basin, slow and continuous compression of the head by an intrapelvic tumour, or perhaps as a child she had always slept on the same side, which according to Virchow, caused the premature synostosis of the coronal suture (14). It is relevant to note at this point how, no matter what the cause, the author thinks this deformity is more pronounced in delinquents (15).

That being said, the author was convinced that the skull malformation was responsible for the woman's low intellect (16, 17). In conclusion, in order to reinforce his hypothesis, he reported the views of other scholars: Penta: "anthropological anomalies have immense value when they are many and are found in parts that have more direct relation to the nervous system" (18), Laurent: "the skull deformity reveals a defect or at least an intellectual irregularity" (19) and Venturi "in no way more than the skull, containing the organ that is the direct instrument of the psyche, can faithfully translate the nature of degeneration that has altered the psyche itself" (20).

According to these arguments, skull malformations can indicate a mental irregularity that may occur through complex disorders of the nervous system, with atypical behaviour. In this regard, it is also interesting to note that some scholars of that time tried to find corroboration in the Lombrosian theories of the Criminal Anthropology. In particular, Goring made a statistical study on 3000 English convicts, in which he proposed to establish whether there were physical or mental anomalies in the criminal classes 
that distinguished them from ordinary people (21). The study, published in 1913, is one of the most comprehensive criminological works of its time. Goring sustained: "the physical and mental constitution of both criminals and law-abiding people of the same age, height, class and intelligence, are identical. There is no such thing as an anthropological criminal type" (21). Through his work, he became convinced that it was not only physical features that were related to criminal behaviour but also environmental factors (22).

It is now known that these theories have been discredited due to the absence of scientific foundation but it is clear that the evolution of both scientific and social theories of that time, together with the contribution of De Blasio which we are now learning about, contributed to the birth of forensic psychopathology (23).

\section{Conclusion}

We would like to conclude this article by pointing out other issues that should be taken into consideration in the studies concerning Criminal Anthropology, that is, the abuse in the past of the mortal remains of the poor in medical research, but also today's ethical issues concerning the study and the museum exposition of human remains $(24,25)$. The case of the denied request to rebury Villella's skull, studied by Lombroso, is an exemplary case (7).

\section{What is already known on this topic}

We know that in the age of Positivism, anthropology, particularly the Lombrosian kind, interpreted human behavior through naturalistic observation. The case presented here is a testimony to how the psychiatry of that time exploited the theories of Criminal Anthropology.

\section{What this study adds}

This study presents a case of a very unusual published autopsy report. The author of the report, Abele De Blasio, doctor and anthropologist, is little known by the scientific community but certainly represents one of the most interesting figures among the followers of Criminal Anthropology.
Authors' contributions: Conception and design: ML; Acquisition, analysis and interpretation of the data: ML; Drafting of the article: ML; Revising it critically for important intellectual content: MT, OL, SI, and CT; Approved final version of the manuscript: ML, OL, CT and SI.

Conflict of interest: The authors declare that they have no conflict of interest.

\section{References}

1. Borgo M, Martini M, Bragazzi NL, Paluan F, Vecchio I, Licata M. Corpus loquens: the speaking body and Abele De Blasio (1858-1945). Acta Med Medit. 2017;33(1):95-100.

2. De Blasio A. Multiple anomalies in the skull of a prostitute. Rivista di Psichiatria Forense, Antropologia Criminale e Scienze Affini. 1900;3:293-301.

3. Licata M. A pyramid skull of an epileptic (1901). Anthropological diagnose of a positivistic physician. Neurol Sci. 2018;39(4):773-5.

4. De Blasio A. The human remains discovered at the Observatory [in Italian]. Rivista di Psichiatria Forense, Antropologia Criminale e Scienze Affini. 1900;3:394-6.

5. De Blasio A. Pyramoid skull in an epileptic [in Italian]. Rivista di Psichiatria Forense, Antropologia Criminale e Scienze Affini. 1901;4:117-22.

6. De Blasio A. Crime and geometric shape of the face among the Neapolitan criminals [in Italian]. Rivista di Psichiatria Forense, Antropologia Criminale e Scienze Affini. 1901;4:285-98.

7. Ciliberti R, Monza F, De Stefano F, Licata M. The trial of the skull studied by the founder of Criminal Anthropology: The war of the Lombroso $\mathrm{Mu}$ seum. J Forensic Leg Med. 2018;59:13-15.

8. Lombroso C, Ferrero O. The criminal woman, the prostitute and the normal woman [in Italian]. Torino-Roma: L. Roux C.;1893.

9. Polo S. The transformation of the concept of a criminal woman from Lombroso to the present day [in Italian]. Rivista di Psicodinamica Criminale. $2008 ; 1(1): 1-15$.

10. Amadei G. The paroccipital process and the pars mastoidea of the temporal of mammals in man [in Italian]. Archivio per l'Antropologia e l'Etnologia. 1880;9:2.

11. Mantegazza P. A case of rare malar bone anomaly [in Italian]. Archivio per l'Antropologia e l'Etnologia. 1872;2:164.

12. Nicolucci G. A new case of rare malarial bone anomaly in humans [in Italian]. Giornale della Reale Accademia di Medicina di Torino. 1871;9. 
13. Giuffrida-Ruggeri V. A new pitecoid character in 13 skulls of alienates [in Italian]. Rivista sperimentale di Freniatria. 1898;24:107.

14. Persing JA, Jane JA, Shaffrey M. Virchow and the pathogenesis of craniosynostosis: a translation of his original work. Plast Reconstr Surg. 1989;83(4):738-42.

15. De Blasio A. The gypsies of Naples [in Italian]. Rivista di Psichiatria Forense, Antropologia Criminale e Scienze Affini. 1902;5:173-85.

16. De Blasio A. Drilled Skull of the Incas Country; Mummies and Cranes of ancient Peru [in Italian]. Rivista di Psichiatria Forense, Antropologia Criminale e Scienze Affini. 1902;5:41-50.

17. De Blasio A. Mummies and Cranes of ancient Peru preserved in some Museums of the University of Naples [in Italian]. Rivista di Psichiatria Forense, Antropologia Criminale e Scienze Affini. 1900;3:169-89.

18. Penta P. On the pathogenetic mechanism, the meaning and the clinical value of anthropological anomalies in Psychiatry and in Criminal Anthropology [in Italian]. Rivista di Psichiatria Fo- rense, Antropologia Criminale e Scienze Affini. 1900;3:193-208.

19. Laurent A. Physiognomy and mimicry of the insane [in French]. Archives de Neurologie. 1905:425-48.

20. Venturi S. Psycho-sexual degeneration in the life of individuals and in the history of societies [in Italian]. Turin: Fratelli Bocca; 1892.

21. Goring C. The English convict: a statistical study. London: HMSO; 1913.

22. Heidt J, Wheeldon JP. Introducing Criminological Thinking. Thousand Oaks: SAGE Publications; 2015.

23. Iorio S, Larentis O, Licata M. Show Me the Shape of your Face and I Will Tell You What Crime You Have Committed. Am J Forensic Med Pathol. 2018;39(3):282-3.

24. Licata M, Monza F. Ethical issues in paleopathological and anthropological research experiences. Acta Biomed. 2017;88(3):315-8.

25. Monza F, Licata M. Anatomical preparations in museums a special category of cultural heritage [in Italian]. Medicina nei Secoli. 2015;27(2):61528. 